\title{
The effect of Daniel's model on the development of critical thinking in the subject of Arabic language among students of the College of Management and Economics
}

\author{
${ }^{1}$ Assist. Prof. Rafid Sabah al-Tamimi, ${ }^{2}$ Dr. Khamael Shakir Ghanim \\ ${ }^{1}$ College of Management and Economics, University of Baghdad \\ ${ }^{2}$ Center for the Revival of the Arab Scientific Heritage, University of Baghdad
}

\section{ABSTRACT}

This research aims to identify the impact of Daniel's model on the development of critical thinking. In order to achieve this objective, the following hypotheses are formulated:

1. There is no statistically significant difference at the significance level $(0.05)$ between the average differences in the posttest scores of the experimental group taught according to Daniel's model and the control group taught according to the traditional method in the measure of critical thinking.

2. There is no statistically significant difference at the significance level (0.05) between the average differences in the preand post-tests scores of the experimental group taught according to Daniel's model in the measure of critical thinking.

The current research is limited to a sample of the first stage students in the department of statistics, College of Management and Economics, Baghdad University for the academic year 2019-2020. The California critical thinking test is applied in the post-test to the control group, which consisted of (47) students, and the experimental group, which consisted of (44) students. After using Ttest for two independent and related samples, the results show that:

1. There is a statistically significant difference between the average of the scores of the two research groups in favor of the experimental group. Therefore, the null hypothesis rejected and the alternative hypothesis is accepted that there is a statistically significant difference between the average of scores of the experimental and control groups in the post-test of critical thinking.

2. There is a statistically significant difference between the average of scores of the experimental group students in the preand post-tests of the creative thinking. This refers to a development in the critical thinking among the students of the experimental group.

In the light of the results, a number of conclusions, recommendations and suggestions are presented at the end of this research.

\section{Introduction}

\section{Research Problem}

Beginning an activity requires thinking about it. When considering its advantage and usefulness, a plan should be designed to implement the required activity and then evaluate it to find out the problems and challenges encountered and how they were faced to achieve the goals. If the activity begins with an idea, then the intellectual aspects supporting the process of thinking should be developed. Thinking is a human skill that has different outcomes depending on the type of task performed using analytical, creative or critical thinking (Yasin \& Amin, 1991). There has been a great interest in critical thinking since the beginning of the 1970s to the present day (Abdullah, 1999). Developing this kind of thinking has become an essential goal for most educational policies in the world and a major objective that the curriculum seeks to achieve (Kneedler, 1986). Particularly, the world today is witnessing radical transformations that have covered the economic, social, scientific and political fields. This represents a qualitative revolution in electronic devices and various communication means through which the individual receives a huge amount of information and knowledge to learn about different cultures. Consequently, it is said that the world has become a small village that can be accessed by any individual (Ali, 2004).

Therefore, educational institutions must deal positively with these data, interactions and complexities. This will only be achieved by preparing critical intellectuals who are able to evaluate information, make judgments and decisions. However, the development of critical 
thinking is not an easy process. Education needs to achieve this process by creating experiences and activities commensurate with the different stages of thinking among students (ash-Shiab, 2000). Smith (1977) raised a question about whether teachers know the abilities of critical thinking. The results showed that more than $50 \%$ of study sample, which consisted of 368 teachers in the United States, do not have the basic skills of critical thinking. This reflects that teachers are unable to provide these skills to their students as long as they do not have them. It is believed that failure to train teachers to this area also means a failure to train students in the future (ash-Shiab, 2000).

Also, the teaching methods commonly used in the field of education continue to pay great attention to memorization and recall and rarely pay attention to the practice of higher mental processes. This in turn transforms the student into a robot that has nothing new except what is stored in it of orders and instructions. This is a common problem in most of schools. Consequently, the educationalists conclude that one of the causes of the deterioration of education is the lack of attention to the higher levels of thinking and neglect of training students how to acquire, process and employ information and developing their mental processes. Daniel's model belongs to the constructivism theory, which focuses mainly on the acquisition and development of concepts and thinking through nine steps. Several studies have been conducted in this aspect such as aj-Jabawi (2011), al-Ghribawi (2011) and as-Saadi (2008). Daniel's model was employed in the experiment on the development of critical thinking in Arabic language among students of the College of Management and Economics. So, the problem of research can be defined in the following question:

- What is the effect of Daniel's model on the development of critical thinking in Arabic language among students of the College of Management and Economics?

\section{Research Objective}

This research aims to identify the effect of Daniel's model on the development of critical thinking.

\section{Research Hypotheses}

In order to achieve research objective, the following hypotheses were formulated:

1. There is no statistically significant difference at the significance level (0.05) between the average differences in the scores of the critical thinking post-test of the experimental group studied according to Daniel's model and the control group studied according to the traditional method.

2. There is no statistically significant difference at the significance level (0.05) between the average differences in the scores of the critical thinking pre- and posttest of the experimental group studied according to Daniel's model.

\section{Research Significance}

Thinking represents the most complex forms of human behavior. It comes at the highest levels of mental activity and is considered one of the most important characteristics that distinguish man from other creatures (Qatami, 2001). If a person wants to think, s/he must have a scientific background to support his/her thinking. Hence, human must pay attention to thinking and benefit from it in different aspects of life, such as economic, health, social, cultural... etc. (Al-Haidari, 2000). In fact, thinking is of great importance in human life, it helps individuals to solve many problems and avoid risk by anticipation because of inferences and analysis. In addition, intellectual processing of things surrounding human beings is a prerequisite for any desired progress. The value of thinking in the educational field continues to grow; therefore, specialists are paying attention to thinking as one of the skills that individuals must acquire during 
the learning process. This motivates them to improve and promote this skill (Yasin \& Amin, 1991).

Critical thinking is based on the application of rules in different situations. It carefully analyzes opinions, ideas and available information to determine their consistency and conformity to known rules and contexts (An-Nuaimi \& Al-Ajili, 2004). Critical thinking is one of the important patterns of thinking provided by psychological and educational studies in the field of mental abilities. Nevertheless, determining the nature of critical thinking is extremely difficult because of the multiplicity of concepts presented by those studies and the disagreement of researchers on the nature of critical thinking and definition of its abilities and methods of measurement (as-Samara'ai, 1994). Although teachers seek to create critical thinking as the primary goal of their teaching, most of them do not realize that this is to improve thinking. Hence, most teachers are unaware of the levels of their intellectual growth. The quality of student's intellectual work will not be achieved if teachers do not realize the degree to which critical thinking develops. Moreover, critical thinking is defined as the ability and tendency to systematically improve the individual's thinking from subjectivity to objective self-assessment (Elder \& Paul, 2005).

The modern perspective argues that science is not only an evolving cognitive construction, but also a dynamic human activity. The real value of science lies in its ability to interpret phenomena and events and this can be achieved by formulating related facts as scientific concepts. Hunter (1991) pointed out that teaching and training students on thinking skills falls under the responsibility of educators and the educational curricula that must provide students with basic thinking skills to help them adapt to renewed changes.

Based on the above, the importance of research can be summarized as follows:
1. Dealing with university students is of great importance as they are the makers of the future, so any attention paid to them is to secure the future of the nation.

2. Research may be a feedback for the research community due to its information about the importance of educational models.

3. It contributes to a theoretical addition based on information about critical thinking.

4. It contributes to providing an applied vision of the programs to be followed in the development of critical thinking.

5. The adoption of teaching strategies makes the student think logically to analyze the causes and relationships that link them with the results within a conceptual framework that makes learning more effective and stable.

\section{Research Scope}

The current research is limited to the first-stage students of the department of statistics in the College of Management and Economics at Baghdad University for the academic year 2019. 2020, the first semester.

\section{Definition of Terms}

The effect is defined as a cognitive product or a dynamic activity generated as a result of the human act represented by the subject of research and influenced by it intentionally (Isa, 2012).

Model is defined as the important overlapping, interrelated and interacting procedures that lead to the development of educational materials to achieve specific goals directed to certain learners in the light of theoretical concepts and principles (al-Hillah, 2003). 
Daniel's Model is defined as a cognitive learning model in which the teacher follows nine steps to achieve understanding including: instructional, review, overview, investigations/activities, representation, discussion, invention, application, and summary/closure (al-Khalili et al., 1996). It is also defined as a cognitive educational model for organizing the teaching of concepts contained in the subject under research of the experimental group and includes a set of procedures based on instructional, review, overview, investigations/activities, representation, discussion, invention, application, and summary/closure (Al-Ghribawi, 2011).

The researcher defines it as a model based on cognitive constructive theory, and is an educational model based on instructional, review, overview, investigations/activities,

representation, discussion, invention, application, and summary/closure by benefitting from the design of the learning course and concept plans.

Procedurally, it is defined as a series of stages aimed at developing critical thinking in the subject of Arabic language among students of the Department of Statistics, College of Management and Economics.

Critical thinking is defined by Fasione et al. (1998) as a self-regulating judgement aimed at interpretation, analysis, evaluation and inference; besides, it explains considerations relating to evidence, concepts, methods and measures on which the judgement reached is based. It consists of five skills:

Analysis Skill: it means to identify relationships with intended and actual connotations between phrases, questions, concepts, qualities and other forms to express a judgment, experience, information or opinion. It consists of sub-skills, including the examination of views, analysis and discussion of arguments.
Induction Skill: it means that the validity of the results is associated with the validity of the antecedents. Among examples of this skill are scientific proofs and experiments. The statistics are considered inductive even if are based on a prediction or probability. It also includes the indications and judgments issued by the person after referring to a situation or event.

Inference Skill: it refers to the practice of a set of processes that rely on generating arguments and assumptions, searching for evidence, reaching results, and identifying associations and causal relationships.

Deductive Skill: it refers to identifying and providing the necessary elements to draw the logical conclusions of intentional or actual inference relationships from phrases, adjectives, questions, or any other form of expression. It also means the ability to create or form an argument or debate through logical steps. The sub-skills of deduction include examining the evidence, guessing alternatives, and reaching conclusions.

Evaluation Skill: measuring the validity of phrases or other expressions will describe a person's understanding and perception. It describes a person's experience, status, judgment, belief, opinion, and thus measuring the logical force of intentional or actual inference relationships among phrases, attributes, questions, or any other form of expression. It includes two sub-skills, namely, evaluating claims and evaluating arguments (Fasione et al., 1998).

The researcher adopted this definition because the California critical thinking test is designed based on it. The procedural definition of critical thinking refers to the total score obtained by the respondent in the California test used in the current research.

\section{Theoretical Framework and Literature Review}

\section{Daniel's Model}


Daniel Neal, Charles Anderson and their colleagues created the Cognitive Instructional Model in 1987. This model is designed based on ideas and was included in the learning course and advanced systems and plans of concepts. The instructional method reflects the teacher's attention on the learning outcomes of his students. Hence, the teacher explains the subject through presenting basic information that benefits students and they cannot access it. Then, he motivates students' interest in learning and mastering facts, rules and necessary procedures for subsequent learning. In addition, he prepares for an activity taught indirectly where he reviews the previous information, reminds students of scientific laws and rules, explains them how to do the work required and how to operate and install the devices, and to draw scientific conclusions and experiences in the context of other teaching methods (AlKhalili et al., 1996).

\section{Stages of the Cognitive Instructional Model} (Daniel's Model)

Daniel's model is a constructive model created by Daniel Neal in 1987. It includes the following stages:

1. Instructional: at this stage, the teacher begins to present a general introduction to the objectives of the lesson and its content. The purpose of this stage is to focus the students' attention on the tasks required and to motivate them towards learning.

2. Review: at this stage, previous lessons related to the new lesson are discussed in order to prepare the students for the current lesson.

3. Overview: at this stage, a general and preliminary overview of the new information or problem under study, and students' ideas are provoked by cognitive charts to understand the problem or phenomenon to be learned.
4. Investigations/Activities: here, students deal with tools and devices, and carry out manual work through experimentation activities to test their ideas. The teacher can carry out the experiment practically (if the teacher fears for the safety of students) by raising questions and providing hints to help students to find solutions.

5. Representation: at this stage, students express their answers to the questions raised by the teacher, and express their findings.

6. Discussion: it refers to the discussion of the results of the activity reached by the students. The teacher asks some questions such as: What did you find? What did you do? Why did it happen? What evidence did you find to support your opinion?

7. Invention: at this stage, cognitive structure is redesigned to ensure meaningful learning for the learner. The teacher gives the correct interpretations of the concept to be learned and identifies and addresses the forms of misperception.

8. Application: new knowledge is being experimented within other new situations.

9. Summary/ Closure: The teacher here summarizes the results and explanations and gives a conclusion to the lesson (AlKhalili et al., 1996).

\section{Advantages of Daniel's Model}

Daniel's model is one of the cognitive teaching models that depend on meaningful learning. This model has the following characteristics:

1. It develops thinking skills, basic science processes such as observation, prediction, measurement, etc., and integration such as interpretation and variable adjustment. 
2. It helps learners to obtain and construct information through discovery and participation in collaborative activities.

3. It contributes to the development of different intelligences among learners, including mathematical logical intelligence through the stage of representation and the use of tables and calculations, as well as interactive intelligence through interaction with others, and natural intelligence through dealing with tools in the investigation stage.

4. It attracts attention and stimulates motivation through presentation of the activities.

5. There is flexibility in the use of activities and means that promote education.

6. The consistent steps of explanation, interpretation, and discussion of a model allow students to acquire knowledge constructively which is sought by builder sought (Muslim, 2015).

\section{Scientists' Viewpoints on Criticall Thinking}

Michel Scranton and Richard Powell, experts in teaching critical thinking, believes that critical thinking is a process of intellectual training and awareness with skill and activity, application, analysis and construction, and evaluation of information taken or derived from experience and observation, reactions, or communication as evidence of belief and action in its form. For example, it depends on general intellectual values and principles, which go beyond the parts of subject in terms of clarity, accuracy, consistency, relevance, acoustic evidence, good results, depth, breadth of thinking and justice. It follows the choice of those structures or compositions or elements of thinking and includes all the reasons such as tasks and problems or discussion of a question, assumptions, concepts, experimental growth, finding conclusions and the objections resulted from alternative viewpoints. Critical thinking is a response to the variable of subject matter, discussions and purposes and the integration of a range of common ideas, including scientific thinking, historical mathematical thinking, human thinking, economic thinking, ethical thinking, philosophical thinking, clear thinking, attentive thinking, independent thinking and all the higher thinking skills in Bloom's taxonomy. Feely (1976) believes that there are three groups of opinions on critical thinking:

The first group opines that critical thinking is any mental activity higher than comprehension in Bloom's taxonomy of cognitive goals.

The second group considers that critical thinking is a kind of judgment in cases. It is clear that the opinion of the first and second groups is comprehensive. For Dewey, thinking is accompanied by a wide range of intellectual activities.

The third group is closer to the evaluation stage in Bloom's taxonomy. This group gives critical thinking an accurate analysis because the five abilities presented in the test of Watson \& Glasser (knowledge of assumptions, interpretation, evaluation of arguments, inference and conclusion) are part of the evaluation in terms of meaning. Each test situation of these abilities requires the examiner to judge the situation in the light of the test items contained in it. Certainly, this does not neglect the opinions of the other two groups as it contains an important aspect, which is comprehension of situation before answering it and sometimes requires reflection in general. Critical thinking can consist of two elements:

1. The information base, the formation of belief and possession of skills.

2. Habit based on the intellectual commitment to use these skills to guide behavior in such a way differs from 
a. Acquisition and memorization of information because it requires a special method of research and processing information.

b. Possessing a set of skills because it requires continuous use of them.

c. Using these skills as a practical aspect without agreement with their results (Scriven \& Paul, 2005).

\section{Research Methodology}

A number of procedures required by the research to reach its objectives and verify its hypotheses were performed as follows:

\section{Experimental Design}

The researcher adopted one of the adjustment designs suitable for research conditions, which is the experimental design with partial adjustment (experimental group and control group), using post-test of subject and critical thinking. The experimental design is clarified in table (1).

Table 1: research groups

\begin{tabular}{|l|l|l|l|}
\hline Group & $\begin{array}{l}\text { Independent } \\
\text { variable }\end{array}$ & Dependent variable & Post-test \\
\hline Experimental & Daniel's model & Critical thinking & $\begin{array}{l}\text { Test of critical } \\
\text { thinking }\end{array}$ \\
\hline Control & Traditional method & & \\
\hline
\end{tabular}

\section{Research Community and Sample}

The researcher purposefully selected department of statistics, College of Management and Economics at University of Baghdad as it includes two groups for the first stage during the academic year 20192020. Group (a) was chosen to be the control group and group (b) represented the experimental group exposed to the independent variable (Daniel's model). Table (2) clarifies the research sample.

Table 2: number of students of the two research groups before and after exclusion

\begin{tabular}{|l|l|l|l|l|}
\hline Main Group & Sub-group & $\begin{array}{l}\text { Number of } \\
\text { students before } \\
\text { exclusion }\end{array}$ & $\begin{array}{l}\text { Number of } \\
\text { failed students }\end{array}$ & $\begin{array}{l}\text { Number of } \\
\text { students after } \\
\text { exclusion }\end{array}$ \\
\hline Control & A & 47 & 3 & 44 \\
\hline $\begin{array}{l}\text { First } \\
\text { Experimental }\end{array}$ & B & 51 & 4 & 47 \\
\hline Total & & 98 & 7 & 91 \\
\hline
\end{tabular}

\section{Equivalence of Research Groups}

1. Age calculated in months
The students' age was calculated by the number of months, where the date of birth of each student was obtained directly from students themselves. The ages were confirmed using the information of enrollment. The arithmetic mean of the age of the 
students of the experimental group was (217.7) months and that of the control group was (217.5) months. In order to identify the significance of the differences between the two groups, T-test was used for two independent samples. The calculated T-value was (1.869), while the tabulated value was
(2.009) at the significance level (0.05), i.e., statistically non-significant. This means that there are no statistically significant differences between the two groups in terms of age, as shown in table (3).

Table 3: Results of T-test for age between the experimental and control groups

\begin{tabular}{|c|c|c|c|c|c|c|}
\hline \multirow[t]{2}{*}{ Group } & \multirow[t]{2}{*}{ Number } & \multirow{2}{*}{$\begin{array}{l}\text { arithmetic } \\
\text { mean }\end{array}$} & \multirow{2}{*}{$\begin{array}{l}\text { Standard } \\
\text { deviation }\end{array}$} & \multicolumn{2}{|l|}{ T-value } & \multirow{2}{*}{$\begin{array}{l}\text { Significance } \\
\text { level }(0.05)\end{array}$} \\
\hline & & & & Calculated & Tabulated & \\
\hline Experimental & 44 & 217.7 & 0.458 & \multirow{2}{*}{1.869} & \multirow{2}{*}{2.009} & \multirow{2}{*}{$\begin{array}{l}\text { No } \\
\text { differences }\end{array}$} \\
\hline Control & 47 & 217.5 & 0.566 & & & \\
\hline
\end{tabular}

\section{Scores of the critical thinking test}

The researcher applied the California critical thinking test before applying the experiment to the two groups. The arithmetic mean was found for the experimental and control groups. The average score of the experimental group was (18.997) and that of the control group was (18.898). In order to identify the significance of differences between the two groups, T-test was used for two independent samples. The calculated T-value was (0.901), which is smaller than the tabulated T-value (2.009) at the significance level (0.05), i.e., statistically non-significant. This means that there are no statistically significant differences between the two groups in critical thinking, as shown in table (4).

Table 4: Results of T-test for average scores in the critical thinking pre-test between the two groups

\begin{tabular}{|c|c|c|c|c|c|c|}
\hline \multirow[t]{2}{*}{ Group } & \multirow[t]{2}{*}{ Number } & \multirow{2}{*}{$\begin{array}{l}\text { arithmetic } \\
\text { mean }\end{array}$} & \multirow{2}{*}{$\begin{array}{l}\text { Standard } \\
\text { deviation }\end{array}$} & \multicolumn{2}{|l|}{ T-value } & \multirow{2}{*}{$\begin{array}{l}\text { Significance } \\
\text { level }(0.05)\end{array}$} \\
\hline & & & & Calculated & Tabulated & \\
\hline Experimental & 44 & 18.997 & 0.671 & \multirow{2}{*}{0.901} & \multirow{2}{*}{2.009} & \multirow{2}{*}{$\begin{array}{l}\text { No } \\
\text { differences }\end{array}$} \\
\hline Control & 47 & 18.898 & 0.358 & & & \\
\hline
\end{tabular}

\section{Intelligence}

The researcher relied on Raven's intelligence test because it is one of the tests applied to the Iraqi environment to verify the equivalence of the two research groups. The test consisted of sixty questions distributed to the students of the experimental and control research groups (1 mark per question). The average score of intelligence of the two groups was calculated. The arithmetic mean of the experimental group was (28.309) scores, while that of the control group was (28.289). T-test was applied to two independent samples to determine the significance of the difference between the two groups. The results showed that there is no statistically significant difference at the significance level (0.05). The calculated T-value was $(0.122)$, which is smaller than the tabulated T-value (2.009) with freedom degree of (89). This indicates that the two research groups are equal in this variable, as shown in table (5).

Table 5: results of T-test of the average scores of intelligence between the two groups 


\begin{tabular}{|l|l|l|l|l|l|l|}
\hline Group & Number & arithmetic & $\begin{array}{l}\text { Standard } \\
\text { mean }\end{array}$ & \multicolumn{2}{|l|}{ T-value } & Significance \\
\cline { 5 - 7 } & & & deviation & Calculated & Tabulated & level (0.05) \\
\hline Experimental & 44 & 28.309 & 0.733 & 0.122 & 2.009 & $\begin{array}{l}\text { No } \\
\text { differences }\end{array}$ \\
\hline Control & 47 & 28.289 & 0.843 & & & \\
\hline
\end{tabular}

\section{Research Tools}

\section{Testing topics of Arabic language}

The researcher followed the following steps when designing the test:

a. Determining the scientific material: the scientific material to be taught for students of research groups during the experiment according to the vocabulary of the curriculum included the following topics: Amro bin Kulthoum (poem: Aba Hind), Ka'ab bin Zuhair (poem: pant Suad), Hassan bin Thabet (poem: this is Mohammed), al-Farazdaq (poem: The One Who creates heaven).

b. Formulating behavioral objectives: the researcher formulated (20) behavioral objectives based on the general objectives and the content of the topics to be taught in the experiment, distributed to the six levels of Bloom's taxonomy (knowledge, comprehension, application, analysis, synthesis and evaluation). In order to determine their validity and fulfilling the content of the subject, they were presented to a group of experts and specialists in Arabic language and methods of its teaching and psychological sciences. After obtaining experts' views, some objectives were modified and all items were kept due to obtaining agreement by $(80 \%)$ of experts' approval. Thus, the number of behavioral objectives was (20).

c. Preparation of teaching plans: since the preparation of teaching plans is one of the requirements of successful teaching, the researcher prepared teaching plans for the subjects of Arabic language to be taught in the experiment in the light of the content, behavioral objectives and Daniel's model for the experimental group. Samples of these plans were presented to a group of experts and specialists in Arabic language and methods of its teaching to improve these plans and ensure the success of the experiment. Based on experts' opinions, some plans were modified.

d. Preparing the test plan: the researcher prepared a test plan of the subjects to be taught in the experiment and included four subjects. The weights of the contents were calculated in the light of the number of pages, and the weights of the objectives levels depended on the number of behavioral objectives in each level according to the objectives of each topic to the total number of objectives. The number of test items was determined by (20) objective items distributed to the fields of the test plan as shown in table (6).

Table 6: Specification table (test plan)

\begin{tabular}{|c|c|c|c|c|c|c|c|c|}
\hline Objectives & No. of & Relative & Items o & f achievement te & & & & Total \\
\hline Content & & & Recall & Understanding & Application & Analysis & Evaluative & \\
\hline
\end{tabular}




\begin{tabular}{|l|l|l|l|l|l|l|l|l|}
\hline First topic & 2 & $\% 25$ & 1 & 1 & 1 & 1 & 1 & 5 \\
\hline $\begin{array}{l}\text { Second } \\
\text { topic }\end{array}$ & 2 & $\% 25$ & 1 & 1 & 1 & 1 & 1 & 5 \\
\hline Third topic & 2 & $\% 25$ & 1 & 1 & 1 & 1 & 1 & 1 \\
\hline $\begin{array}{l}\text { Fourth } \\
\text { topic }\end{array}$ & 2 & $\% 25$ & 1 & 1 & 1 & 1 & 1 & 5 \\
\hline Total & 8 & $\% 100$ & 4 & 4 & 4 & 4 & 4 & 20 \\
\hline
\end{tabular}

\section{The Test Validity}

Validity is one of the characteristics of the good test. In order to confirm the validity of the test prepared by the researcher, it was presented to a number of experts and specialists in Arabic language and methods of its teaching, education and psychology to judge the validity of items in measuring what to be measured. After obtaining experts' opinions, some items were modified and all items were kept due to having agreement by $(80 \%)$ of experts' approval. Thus, the number of behavioral objectives was (20).

\section{Exploratory Experiment}

For determining the time taken to answer the test and the clarity of its items, the experiment was applied to a sample consisting of (20) students. It was found that the items were clear for the students, and the average time spent in the answer was (45) minutes.

\section{Statistical Analysis of the Test Items}

The test was applied to (100) students selected from the first stage in the department of statistics. To facilitate statistical procedures, the researcher arranged the scores in descending form from the highest to the lowest score. Then, the highest and lowest samples were selected by $(27 \%)$ as the best two groups to represent the whole community. The following tables clarify the statistical analysis procedures for the test items.

\section{Level of Items Difficulty}

Table 7: coefficients of test items difficulty

\begin{tabular}{|l|l|l|l|l|l|l|l|}
\hline \multicolumn{9}{|l|}{ First question } & \multicolumn{4}{l|}{ Second question } \\
\hline $\begin{array}{l}\text { No. of } \\
\text { item }\end{array}$ & $\begin{array}{l}\text { Difficulty } \\
\text { coefficient }\end{array}$ & $\begin{array}{l}\text { No. } \\
\text { of } \\
\text { item }\end{array}$ & $\begin{array}{l}\text { Difficulty } \\
\text { coefficient }\end{array}$ & $\begin{array}{l}\text { No. of } \\
\text { item }\end{array}$ & $\begin{array}{l}\text { Difficulty } \\
\text { coefficient }\end{array}$ & $\begin{array}{l}\text { No. of } \\
\text { item }\end{array}$ & $\begin{array}{l}\text { Difficulty } \\
\text { coefficient }\end{array}$ \\
\hline 1 & 0.31 & 6 & 0.40 & 1 & 0.43 & 6 & 0.30 \\
\hline 2 & 0.35 & 7 & 0.42 & 2 & 0.32 & 7 & 0.41 \\
\hline 3 & 0.21 & 8 & 0.43 & 3 & 0.38 & 8 & 0.52 \\
\hline 4 & 0.29 & 9 & 0.42 & 4 & 0.38 & 9 & 0.50 \\
\hline 5 & 0.34 & 10 & 0.42 & 5 & 0.30 & 10 & 0.39 \\
\hline
\end{tabular}

The Discriminative Power of Items

Table 8: coefficients of discriminative power of test items 


\begin{tabular}{|l|l|l|l|l|l|l|l|}
\hline $\begin{array}{l}\text { No. of } \\
\text { item }\end{array}$ & $\begin{array}{l}\text { Discriminat } \\
\text { ive power }\end{array}$ & $\begin{array}{l}\text { No. of } \\
\text { item }\end{array}$ & $\begin{array}{l}\text { Discriminati } \\
\text { ve power }\end{array}$ & $\begin{array}{l}\text { No. of } \\
\text { item }\end{array}$ & $\begin{array}{l}\text { Discriminati } \\
\text { ve power }\end{array}$ & $\begin{array}{l}\text { No. of } \\
\text { item }\end{array}$ & $\begin{array}{l}\text { Discriminati } \\
\text { ve power }\end{array}$ \\
\hline 1 & 0.43 & 6 & 0.24 & 1 & 0.44 & 6 & 0.39 \\
\hline 2 & 0.32 & 7 & 0.43 & 2 & 0.45 & 7 & 0.35 \\
\hline 3 & 0.32 & 8 & 0.50 & 3 & 0.35 & 8 & 0.37 \\
\hline 4 & 0.53 & 9 & 0.35 & 4 & 0.48 & 9 & 0.47 \\
\hline 5 & 0.24 & 10 & 0.51 & 5 & 0.65 & 10 & 0.45 \\
\hline
\end{tabular}

The Discrimination of Alternatives

Table 9: discrimination of alternatives of first question in test

\begin{tabular}{|l|l|l|l|l|l|l|l|}
\hline $\begin{array}{l}\text { No. } \\
\text { of } \\
\text { item }\end{array}$ & $\begin{array}{l}\text { Discriminati of first } \\
\text { on ofternative }\end{array}$ & $\begin{array}{l}\text { Discriminati } \\
\text { on of second } \\
\text { alternative }\end{array}$ & $\begin{array}{l}\text { Discriminati } \\
\text { on of third } \\
\text { alternative }\end{array}$ & $\begin{array}{l}\text { No. } \\
\text { of } \\
\text { item }\end{array}$ & $\begin{array}{l}\text { Discriminati } \\
\text { on of first } \\
\text { alternative }\end{array}$ & $\begin{array}{l}\text { Discriminati } \\
\text { on of second } \\
\text { alternative }\end{array}$ & $\begin{array}{l}\text { Discriminati } \\
\text { on of third } \\
\text { alternative }\end{array}$ \\
\hline 1 & -9 & -11 & -7 & 1 & -5 & -7 & -12 \\
\hline 2 & -8 & -6 & -10 & 2 & -9 & -8 & -13 \\
\hline 3 & -5 & -6 & -7 & 3 & -9 & -5 & -7 \\
\hline 4 & -12 & -4 & -14 & 4 & -13 & -10 & -6 \\
\hline 5 & -10 & -12 & -9 & 5 & -10 & -10 & -9 \\
\hline
\end{tabular}

\section{The Test reliability}

Split-half method was used to calculate the reliability of test. It is one of the most common methods used for calculating reliability. The test is applied one time for reducing time and effort, and then the reliability is calculated by splitting it into two halves or more. The researcher adopted the same statistical analysis sample scores. The test reliability was verified by using retest method with a two-week interval and a sample of (30) students from outside the research sample. Pearson correlation coefficient was calculated. After using Spearman Brown Coefficient, the reliability coefficient was (0.80), which is acceptable for unregulated tests.

\section{The Final Form of Test}

After the completion of the statistical procedures related to the test and its items, (20) items were distributed to two questions: the first question included (10) multiple-choice items and the second question included (10) items of blanks completion.

\section{Critical Thinking Test}

The California critical thinking test was designed based on the definition reached in the consensus of experts at the American Psychological Association (APA) conference. This test includes a measurement of five critical thinking skills: analysis, induction, inference, conclusion and evaluation.

\section{Face Validity}

To verify the clarity of items and their adequacy to the Iraqi environment, the test was presented to a number of experts and specialists in the Arabic language and methods of its teaching, education and psychology to express their opinions on its validity. After obtaining the experts' opinions, some items were modified and all items were kept due to having agreement by $(80 \%)$ of experts' approval. Thus, the test items were (34) distributed among the five skills of critical thinking.

\section{Test Correction}


The California test consists of (34) of multiplechoice items. Each item has four alternatives, and some items have five alternatives ( 1 mark per correct answer and zero for the wrong answer). Thus, the total score of the test ranged from (0-34).

\section{Statistical Means}

The researcher used the following statistical means to analyze the results:

1. T-test for two independent samples to extract the results.

2. Pearson Correlation coefficient to calculate the test reliability.

3. Difficulty coefficient to calculate the difficulty of test items.
4. The discriminative power of items to calculate the coefficients of the discriminatory of test items.

5. The discrimination of alternatives to measure the effectiveness of incorrect alternatives in multiple-choice items in the first question of achievement test.

\section{Results and Discussion}

H1: By comparing the post-test of the two groups, it was found that the average score of students in the experimental group was $(29,387)$ with a standard deviation (0.599), while the average score of the control group was (18.435) with a standard deviation (0.490). Using T-Test of two independent samples to determine the significance of the differences between these two averages, there were statistically significant differences between the two groups, as shown in table (10).

Table 10: T-Test results for two independent samples of the post-test in critical thinking

\begin{tabular}{|c|c|c|c|c|c|c|c|}
\hline \multirow[t]{2}{*}{ Group } & \multirow[t]{2}{*}{ Number } & \multirow{2}{*}{$\begin{array}{l}\text { arithmeti } \\
\text { c mean }\end{array}$} & \multirow{2}{*}{$\begin{array}{l}\text { Standar } \\
\mathrm{d} \\
\text { deviatio } \\
\mathrm{n}\end{array}$} & \multirow{2}{*}{$\begin{array}{l}\text { Freedo } \\
\mathrm{m} \\
\text { degree }\end{array}$} & \multicolumn{2}{|l|}{ T-value } & \multirow{2}{*}{$\begin{array}{l}\text { Significance } \\
\text { level }\end{array}$} \\
\hline & & & & & Calculated & $\begin{array}{l}\text { Tabulate } \\
\text { d }\end{array}$ & \\
\hline $\begin{array}{l}\text { Experiment } \\
\text { al }\end{array}$ & 44 & 29,387 & 0.599 & \multirow[t]{2}{*}{89} & \multirow[t]{2}{*}{96.920} & \multirow[t]{2}{*}{2.009} & \multirow[t]{2}{*}{$(0.05)$} \\
\hline Control & 47 & 18.435 & 0.490 & & & & \\
\hline
\end{tabular}

Table (10) shows that the calculated T-value (96.920) is higher than the tabulated $\mathrm{T}$-value (2.009) with a degree of freedom (89) at the significance level (0.05). This indicates that there is a statistically significant difference between the average scores of students of the two research groups in favor of the experimental group. Therefore, the null hypothesis is rejected and the alternative hypothesis is accepted.
H2: To verify this hypothesis, T-Test was applied to two related samples to determine whether Suchman's model is effective in improving creative thinking among the students of the experimental group. The average differences between the scores of students in the critical thinking test was $(29,387)$ with a standard deviation (0.599) in the post-test and (18.997) in the pre-test with a standard deviation (0.671), as shown in table (11).

Table 11: T-Test results for two related samples of the pre- and post-test in critical thinking of the experimental group 


\begin{tabular}{|c|c|c|c|c|c|c|c|}
\hline \multirow[t]{2}{*}{ Test } & \multirow[t]{2}{*}{ Number } & \multirow{2}{*}{$\begin{array}{l}\text { arithmeti } \\
\text { c mean }\end{array}$} & \multirow{2}{*}{$\begin{array}{l}\text { Standar } \\
\text { d } \\
\text { deviatio } \\
\text { n }\end{array}$} & \multirow{2}{*}{$\begin{array}{l}\text { Freedo } \\
\mathrm{m} \\
\text { degree }\end{array}$} & \multicolumn{2}{|l|}{ T-value } & \multirow{2}{*}{$\begin{array}{l}\text { Significance } \\
\text { level }\end{array}$} \\
\hline & & & & & Calculated & $\begin{array}{l}\text { Tabulate } \\
\text { d }\end{array}$ & \\
\hline Pre & 44 & 29,387 & 0.599 & \multirow[t]{2}{*}{86} & \multirow{2}{*}{78.120} & \multirow{2}{*}{2.009} & \multirow[t]{2}{*}{$(0.05)$} \\
\hline post & 44 & 18.997 & 0.671 & & & & \\
\hline
\end{tabular}

Table (11) shows that the calculated T-value (78.120) is higher than the tabulated $\mathrm{T}$-value (2.009) with a degree of freedom (86) at the significance level (0.05). This indicates that the result is statistically significant for the post-test. Therefore, the null hypothesis is rejected and the alternative hypothesis is accepted. This means that critical thinking is improved among the students of the experimental group who studied according to Daniel's model.

\section{Conclusion}

In the light of results, the researcher concluded that:

1. Daniel's model has transformed the focus from external factors affecting the learner to critical thinking.

2. Daniel's model focuses on paying attention to the learner and providing him with the skills necessary to maintain the learner's centrality, which is one of the most important necessities of this era.

3. Daniel's model is effective in developing critical thinking.

The researcher suggested the following recommendations:

1. Using Daniel's model in teaching Arabic language because of its importance in developing critical thinking skills among university students.

2. Activities and questions that motivate students to think in general and critical thinking in particular in order to develop critical thinking should be included in the Arabic language curriculum for university students.

\section{References}

1. Abdullah, N. (1999). A comparative study of critical thinking among adolescents and the elderly (Master thesis). University of Baghdad, Iraq.

2. Al-Ghribawi, Z. (2011). The effect of models of Daniel and D.A. River on the acquisition of rhetorical concepts among the fifth-grade secondary students at Khawla Bint Al-Azur High School in Baghdad. Basic Education Journal, 66.

3. Al-Haidari, S. (2000). Spiritual education. Beirut, Lebanon: as-Sadiqeen press.

4. Al-Hillah, M. (2003). Educational design: Theory and practice. Amman, Jordan: AlMaseerah press for publishing and distribution.

5. Ali, I. (2004). The effect of a training program on the development of critical thinking among secondary school students (PhD thesis). University of Baghdad, Iraq.

6. Al-Khalili, K. et al. (1996). Teaching science in the general teaching stages. Dubai, UAE: Al-Qalam press for publishing and distribution.

7. An-Nuaimi, T. \& Al-Ajili, S. (2004). Introduction to psychology. Baghdad, Iraq: Scientific Complex Press.

8. ash-Shiab, F. (2000). The effect of using the methods of collaborative learning and 
collective discussion on the development of critical thinking among the students of the tenth elementary grade in geography $(\mathrm{PhD}$ thesis). University of Baghdad, Iraq.

9. As-Samara'ai, Q. (1994). The effect of using the methods of discussion and declamation with the current events on the development of the critic in the subject of history among the second grade students at the teacher training institutes ( $\mathrm{PhD}$ Thesis). University of Baghdad, Iraq.

10. Elder, L. \& Paul, R. (2004). Critical thinking Development: A stage theory with implications for Instruction. Retrieved from: www.critical thinking.org

11. Fasione, P. A, Sanchez (Giancarlo) CA, Fasione, NC \& Gainen, J. (1998). The disposition toward critical thinking. Journal of General Education, 44(1), 1-25, 1998.

12. Hunter, E. (1991). Focus on critical thinking skills across the curriculum. Nass
Bulletin, 75(23).

13. Isa, A. (2012). The effect of the employment of the Kurt program on acquiring rhetorical concepts and developing critical skills among female students of teacher training institutes (unpublished doctoral thesis). Baghdad University, Iraq.

14. Muslim, A. (2015). The impact of the use of the Daniel's model on the development of mathematical concepts and sports communication among the students of the seventh-grade in Gaza (unpublished Master thesis). Faculty of Education, Palestine.

15. Qatami, N. (2001). Thinking education for the elementary stage. Amman, Jordan: alFikr press for printing.

16. Scriven, M. \& Paul, R. (2005). Defining critical thinking. Retrieved from: www.criticalthinking.org

17. Yasin, A. \& Amin, K. (1991). Lessons in thinking education. Teacher's Letter Journal, (1 and 2), Amman. 